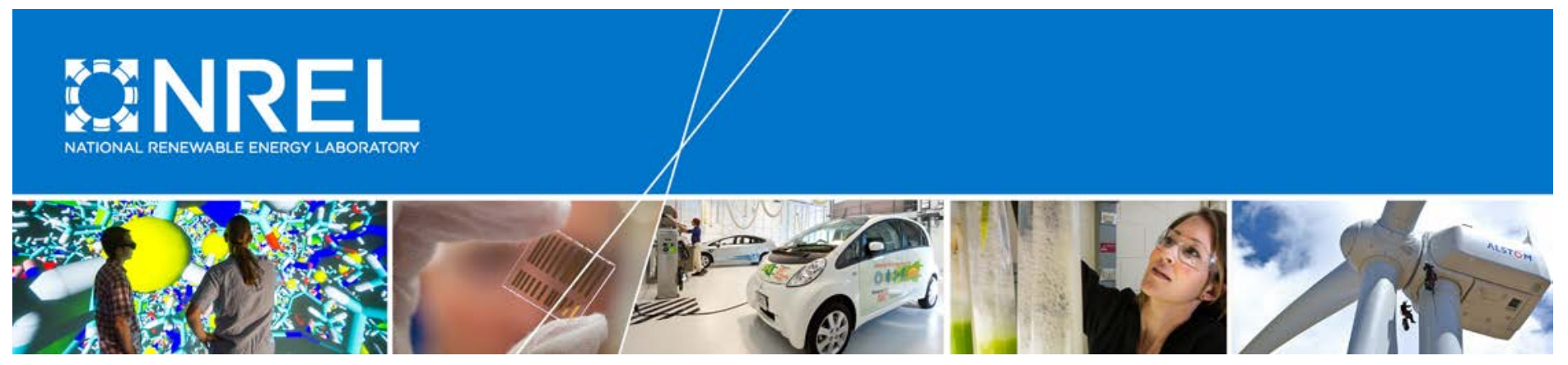

\title{
Moving Toward Quantifying Reliability - The Next Step in a Rapidly Maturing PV Industry
}

\section{Preprint}

Sarah Kurtz ${ }^{1}$, Tony Sample ${ }^{2}$, John Wohlgemuth ${ }^{1}$, Wei Zhou ${ }^{3}$, Nick Bosco ${ }^{1}$, Joerg Althaus ${ }^{4}$, Nancy Phillips ${ }^{5}$, Michael Deceglie ${ }^{1}$, Chris Flueckiger ${ }^{6}$, Peter Hacke ${ }^{1}$, David Miller ${ }^{1}$, Michael Kempe ${ }^{1}$, Masaaki Yamamichi ${ }^{7}$, and Michio Kondo ${ }^{7}$

${ }^{1}$ National Renewable Energy Laboratory; ${ }^{2}$ European Commission, JRC; ${ }^{3}$ Trina Solar; ${ }^{4}$ TUV Rheinland; ${ }^{5} 3 \mathrm{M} ;{ }^{6} \mathrm{UL} ;{ }^{7}$ National Institute of Advanced Industrial Science and Technology (AIST)

Presented at the $43^{\text {rd }}$ IEEE Photovoltaic Specialists Conference New Orleans, Louisiana June 14-19, 2015

(C) 2015 IEEE. Personal use of this material is permitted. Permission from IEEE must be obtained for all other uses, in any current or future media, including reprinting/republishing this material for advertising or promotional purposes, creating new collective works, for resale or redistribution to servers or lists, or reuse of any copyrighted component of this work in other works.

NREL is a national laboratory of the U.S. Department of Energy Office of Energy Efficiency \& Renewable Energy Operated by the Alliance for Sustainable Energy, LLC

This report is available at no cost from the National Renewable Energy Laboratory (NREL) at www.nrel.gov/publications.

\section{Conference Paper}

NREL/CP-5J00-63520

December 2015 


\section{NOTICE}

The submitted manuscript has been offered by an employee of the Alliance for Sustainable Energy, LLC (Alliance), a contractor of the US Government under Contract No. DE-AC36-08GO28308. Accordingly, the US Government and Alliance retain a nonexclusive royalty-free license to publish or reproduce the published form of this contribution, or allow others to do so, for US Government purposes.

This report was prepared as an account of work sponsored by an agency of the United States government. Neither the United States government nor any agency thereof, nor any of their employees, makes any warranty, express or implied, or assumes any legal liability or responsibility for the accuracy, completeness, or usefulness of any information, apparatus, product, or process disclosed, or represents that its use would not infringe privately owned rights. Reference herein to any specific commercial product, process, or service by trade name, trademark, manufacturer, or otherwise does not necessarily constitute or imply its endorsement, recommendation, or favoring by the United States government or any agency thereof. The views and opinions of authors expressed herein do not necessarily state or reflect those of the United States government or any agency thereof.

This report is available at no cost from the National Renewable Energy Laboratory (NREL) at www.nrel.gov/publications.

Available electronically at SciTech Connect http:/www.osti.gov/scitech

Available for a processing fee to U.S. Department of Energy and its contractors, in paper, from:

U.S. Department of Energy

Office of Scientific and Technical Information

P.O. Box 62

Oak Ridge, TN 37831-0062

OSTI http://www.osti.gov

Phone: 865.576.8401

Fax: 865.576.5728

Email: reports@osti.gov

Available for sale to the public, in paper, from:

U.S. Department of Commerce

National Technical Information Service

5301 Shawnee Road

Alexandra, VA 22312

NTIS http://www.ntis.gov

Phone: 800.553 .6847 or 703.605 .6000

Fax: 703.605.6900

Email: orders@ntis.gov 


\section{Moving Toward Quantifying Reliability - The Next Step in a Rapidly Maturing PV Industry}

Sarah Kurtz ${ }^{1}$, Tony Sample ${ }^{2}$, John Wohlgemuth ${ }^{1}$, Wei Zhou ${ }^{3}$, Nick Bosco ${ }^{1}$, Joerg Althaus ${ }^{4}$, Nancy Phillips ${ }^{5}$, Michael Deceglie ${ }^{1}$, Chris Flueckiger ${ }^{6}$, Peter Hacke ${ }^{1}$, David Miller ${ }^{1}$, Michael Kempe ${ }^{1}$, Masaaki Yamamichi ${ }^{7}$, Michio Kondo ${ }^{7}$

${ }^{\mathbf{1}}$ National Renewable Energy Laboratory, Golden, CO, USA; ${ }^{2}$ European Commission, JRC, Ispra, Italy; ${ }^{3}$ Trina Solar, Changzhou, Jiangsu, China; ${ }^{4}$ TUV Rheinland, Cologne, Germany; ${ }^{5} 3 \mathrm{M}$, Saint Paul, MN, USA;

${ }^{6}$ UL, Northbrook, IL, USA; ${ }^{7}$ National Institute of Advanced Industrial Science and Technology (AIST), Tsukuba, Japan

\begin{abstract}
Some may say that PV modules are moving toward being a simple commodity, but most major PV customers ask: "How can I minimize chances of a module recall?" Or, "How can I quantify the added value of a 'premium' module?" Or, "How can I assess the value of an old PV system that I'm thinking of purchasing?" These are all questions that PVQAT (the International PV Quality Assurance Task Force) and partner organizations are working to answer. Defining standard methods for ensuring minimal acceptable quality of PV modules, differentiating modules that provide added value in the toughest of environments, and creating a process (e.g. through IECRE [1]) that can follow a PV system from design through installation and operation are tough tasks, but having standard approaches for these will increase confidence, reduce costs, and be a critical foundation of a mature PV industry. This paper summarizes current needs for new tests, some challenges for defining those tests, and some of the key efforts toward development of international standards, emphasizing that meaningful quantification of reliability (as in defining a service life prediction) must be done in the context of a specific product with design parameters defined through a quality management system.
\end{abstract}

Index Terms - photovoltaic module, reliability, service life prediction, PV system performance.

\section{INTRODUCTION}

As the world seeks $\sim \$ 100$ billion/year to install PV plants, investors seek confidence in long-term PV performance. Incentive programs have sometimes allowed investors to gain a return on their investment even before the project is completed, but as incentives shrink, profitable investment in PV will increasingly require decades of reliable operation.

While PV module efficiencies continue to inch up and module costs inch down, reliability features (e.g., resistance to potential-induced degradation, PID [2], or to humid conditions) are increasingly advertised for new products. PV customers would like to quantify the value of these added features, just as they quantify the value of increased efficiency.

Toward better quantifying risk, PV customers have increased their demands on manufacturers. Table I shows Trina Solar's experience with customers' requests for module acceptance and factory surveillance in recent years. While there is value in these, repeating extended tests for each cus- tomer may add more cost than value. Ideally, PV customers and manufacturers will work together to identify the most valuable tests and optimize the cost-benefit ratio.

TABLE I

SUMMARY OF EXPERIENCE WITH CUSTOMER REQUESTS

\begin{tabular}{|c|c|}
\hline Common customer requests & Year \\
\hline IEC or UL certificate & $\begin{array}{r}2009 \\
2010\end{array}$ \\
\hline $\begin{array}{l}\text { IEC or UL certificate \& } \\
\text { Pre-shipment inspection \& } \\
3^{\text {rd }} \text { party acceptance test (STC power test/EL) }\end{array}$ & $\begin{array}{r}2011- \\
2012\end{array}$ \\
\hline $\begin{array}{l}\text { IEC or UL certificate, Beyond IEC test, PID test \& } \\
\text { Factory audit + Pre-shipment inspection \& } \\
3^{\text {rd }} \text { party acceptance test (STC power test/EL/some } \\
\text { reliability tests) }\end{array}$ & 2013 \\
\hline $\begin{array}{l}\text { IEC or UL certificate, Beyond IEC test, PID test \& } \\
\text { Salt mist corrosion test, Ammonia test \& } \\
\text { Factory audit \& Manufacturing supervision \& } \\
\text { Pre-shipment inspection \& } \\
3^{\text {rd }} \text { party acceptance test (STC power test/EL/some } \\
\text { reliability monitoring tests) }\end{array}$ & 2014 \\
\hline
\end{tabular}

Decades of research on PV testing [3]-[4] have laid a strong foundation for growth of the PV industry. PV reliability has drawn increased interest in recent years with organizations around the world developing new tests [5]-[13].

However, multiple factors prevent the desired confidence, including:

1) Long desired service life ( $>25 y)$,

2) Rapidly evolving product designs (typically $<0.5 \mathrm{y}$ ),

3) Complexity of use environments, and

4) High cost of testing for large sample sets.

As PV products mature, the relationship between product lifetime and product design and quality will slowly become clear. As product designs stabilize, it will be more feasible to test the specific bill of materials and associated process window to provide more quantitative predictions for specific use environments. 
This paper first builds on the previous analysis used for creating Qualification Plus [5], [14] by citing a few recent field observations, then summarizes efforts to implement international standards and strategies to address these needs. Finally, we discuss service life prediction for a specific product that has a well-defined bill of materials and a process window defined by a quality management system.

\section{CURRENT FIELD EXPERIENCE}

Numerous reports have summarized PV field experience [15]-[22]. We previously prioritized electrical-connection failures, cracked cells, PID and weathering of various module components as key issues and described these in Qualification Plus [5], [14]. Table II provides a small update to the Qualification Plus analysis. Although many types of problems are reported, the final experience is usually quite positive: 1) the mean and median of reported degradation rates are typically $0.4-0.8 \%$ [15]-[16], but higher degradation rates are observed statistically for hot locations [18]-[19], and 2) failure rates from many different causes are typically $<1 \% / y$. Newer modules could have different outcomes if testing of new designs has been inadequate.

TABLE II

RECENT OBSERVATIONS TO CONSIDER IN ADDITION TO QUALIFICATION PLUS SUMMARY OF FIELD EXPERIENCE [5, 14]

\begin{tabular}{|l|c|c|}
\hline Observation & $\begin{array}{c}\text { Data } \\
\text { source }\end{array}$ & Needed test \\
\hline $\begin{array}{l}\text { Hotter climates show faster } \\
\text { degradation (average of } \\
>1.4 \% / y \text { relative to average } \\
<0.6 \% / y \text { for cooler climates) }\end{array}$ & {$[18]-[19]$} & $\begin{array}{c}\text { High-temper- } \\
\text { ature tests }\end{array}$ \\
\hline $\begin{array}{l}\text { Installers report that modules } \\
\text { are differentiated by robustness } \\
\text { of frames }\end{array}$ & $\begin{array}{c}\text { NABCEP* } \\
\text { meeting: } \\
\text { New York }\end{array}$ & $\begin{array}{c}\text { Frame } \\
\text { robustness } \\
\text { test }\end{array}$ \\
\hline $\begin{array}{l}\text { PV customers report concern } \\
\text { that PV manufacturers may use } \\
\text { unqualified materials without } \\
\text { adequate testing or engineering } \\
\text { control }\end{array}$ & $\begin{array}{c}\text { Rump } \\
\text { Session }\end{array}$ & $\begin{array}{c}\text { Assessment } \\
\text { of quality } \\
\text { management } \\
6^{* *}\end{array}$ \\
\hline
\end{tabular}

*North American Board of Certified Energy Practitioners

$* * 6^{\text {th }}$ World Conference on PV Energy Conversion

Conclusions about field experience depend on the climate and mounting configuration. Those in hot climates [18]-[19] or using roof top mounting [23] are more concerned with the heat, motivating a durability test at higher temperatures, whereas those in cold climates are concerned with damage from snow and ice, motivating a snow and ice test for robustness of the module package (see NABCEP reference in Table II). In addition to the climate-specific concerns, some common concerns include the effects of cracked cells and other losses of electrical continuity because these can lead to large losses in power and introduction of safety risks [20][22], [24]. Interestingly, although cracked cells have become more common as cells have been thinned in recent years, there are few papers written specifically about cracked cells. Publications more commonly describe "snail trails" (observed when the encapsulant has a different color near the crack than elsewhere - see Fig. 1) and conclude that these decorate cracked cells that lead to substantial power loss [20]. However, instead of identifying the cracked cells as the problem that needs to be fixed, often the cosmetic "snail trails" are identified as "the problem." We have not seen a report that directly links the snail trails to performance loss, but note that the snail trails provide a simple way to identify cracked cells.

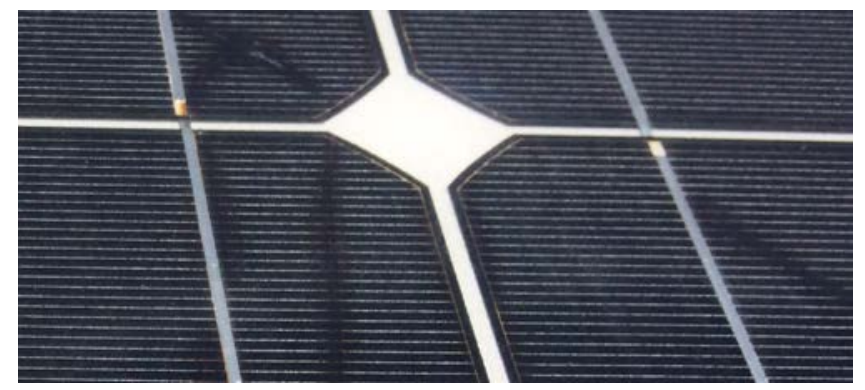

Fig. 1. Image showing "snail trails" that decorate cracked cells; cracked cells often lead to decrease in module performance.

Some PV customers wish to eliminate all cell cracks, but if a cell cracks in such a way that every fragment remains connected, there may not be significant power loss. In order to reduce the silicon usage (and associated module cost) by thinning cells, we need to better understand how to avoid cracks, how to test for them [25]-[27], and how to identify which cracks, if any, are acceptable [28]. Electroluminescence is a useful tool for identifying cracked cells and may help to differentiate cracks that lead to power loss from those that don't [29].

\section{INTERNATIONAL STANDARDS EFFORTS}

Table III provides a summary of the module-level issues that we have prioritized and the near- and long-term plans to address them by PVQAT and Working Group 2 (WG2) (Modules) of IEC Technical Committee 82 (TC82) on PV. In general, PVQAT provides an open forum for researchers to join together in executing research projects to better understand the degradation modes and mechanisms and ways to test for these. The results from these research efforts are used by the IEC standards project groups. Each issue is described in further detail in the sub-sections below. 
TABLE III

INTERNATIONAL STANDARDS EFFORTS TO ADDRESS ISSUES PRIORITIZED IN QUALIFICATION PLUS [5, 14] AND IN TABLE II

\begin{tabular}{|c|c|c|c|}
\hline Priority & Current status & Near Term Plan & Long-Term Plan \\
\hline $\begin{array}{l}\text { A. UV durability of polymeric compo- } \\
\text { nents (encapsulants, backsheets, } \\
\text { connectors and junction boxes); } \\
\text { requirement for insulation materials } \\
\text { (see Qualification Plus component } \\
\text { tests } 1-4 \text { ) }\end{array}$ & $\begin{array}{l}\text { Recent and planned } \\
\text { changes will add more UV } \\
\text { and other testing of poly- } \\
\text { meric materials }\end{array}$ & $\begin{array}{l}\text { 1) Submit IEC 62788-7-2 } \\
\text { [30]; } \\
\text { 2) Submit amendment to } \\
\text { IEC } 61730 \text { [31] referenc- } \\
\text { ing weathering condi- } \\
\text { tions in IEC 62788-7-2 } \\
\text { [30]; } \\
\text { 3) Submit additional IEC } \\
62788 \text { parts; publish in } \\
2016\end{array}$ & $\begin{array}{l}\text { Define climate-specific UV } \\
\text { exposures }\end{array}$ \\
\hline $\begin{array}{l}\text { B. Bypass diode and j-box thermal } \\
\text { tests (see Qualification Plus compo- } \\
\text { nent test 5) }\end{array}$ & $\begin{array}{l}\text { Multiple documents are in } \\
\text { progress to address ther- } \\
\text { mal endurance, cycling, } \\
\text { and runaway }\end{array}$ & $\begin{array}{l}\text { Five actions are } \\
\text { described in text; publish } \\
\text { in } 2016\end{array}$ & $\begin{array}{l}\text { Define climate-specific diode } \\
\text { tests }\end{array}$ \\
\hline $\begin{array}{l}\text { C. Electrical failures within the } \\
\text { module (see Qualification Plus } \\
\text { module test 1) }\end{array}$ & $\begin{array}{l}\text { Ribbon interconnects can } \\
\text { be tested with cyclic } \\
\text { mechanical loading, but } \\
\text { thermal cycling (TC) is also } \\
\text { needed }\end{array}$ & Continue investigations & $\begin{array}{l}\text { Define climate-specific thermal- } \\
\text { cycle tests and implementation } \\
\text { within quality management sys- } \\
\text { tem }\end{array}$ \\
\hline $\begin{array}{l}\text { D. Power loss from cracked cells (see } \\
\text { Qualification Plus module test } 2 \text { ) }\end{array}$ & $\begin{array}{l}\text { IEC/TS } 62782 \text { [32] and } \\
\text { IEC } 62759-1 \text { [33] are } \\
\text { submitted as final drafts; } \\
\text { publish in } 2015\end{array}$ & $\begin{array}{l}\text { Submit amendment to } \\
\text { IEC } 61215 \text { [34] to add } \\
1000 \text { cycles DML before } \\
\text { TC and humidity freeze }\end{array}$ & $\begin{array}{l}\text { Define climate-specific tests for } \\
\text { cracked cells, if needed }\end{array}$ \\
\hline $\begin{array}{l}\text { E. Susceptibility to PID (see } \\
\text { Qualification Plus module test 3) }\end{array}$ & $\begin{array}{l}\text { IEC/TS } 62804-1 \text { [35] has } \\
\text { been submitted as a Draft } \\
\text { Technical Specification; } \\
\text { publish in } 2015\end{array}$ & $\begin{array}{l}\text { Publish IEC } 62804 \text { [35] } \\
\text { and define standard } \\
\text { labels for PID } \\
\text { susceptibility }\end{array}$ & $\begin{array}{l}\text { Understand relationship } \\
\text { between degradation in the test } \\
\text { and in the field; Identify quick } \\
\text { tests for screening cells and } \\
\text { encapsulant materials }\end{array}$ \\
\hline $\begin{array}{l}\text { F. Susceptibility to hot spot degrada- } \\
\text { tion (see Qualification Plus module } \\
\text { test } 4 \text { ) }\end{array}$ & $\begin{array}{l}\text { Revised hot-spot test is } \\
\text { proposed in edition } 3 \text { of } \\
\text { IEC } 61215 \text { [34] }\end{array}$ & $\begin{array}{l}\text { Publish edition } 3 \text { of IEC } \\
61215 \text { [34] in } 2015\end{array}$ & $\begin{array}{l}\text { Define improved hot-spot test } \\
\text { for thin-film modules }\end{array}$ \\
\hline $\begin{array}{l}\text { G. Improve confidence in Quality } \\
\text { Management System (QMS) (see } \\
\text { Qualification Plus description of sam- } \\
\text { pling and QMS) }\end{array}$ & $\begin{array}{l}\text { IEC/TS } 62941 \text { [36] may be } \\
\text { submitted in June } 2015 \text { as } \\
\text { a Draft Technical } \\
\text { Specification }\end{array}$ & $\begin{array}{l}\text { Publish in 2015; Imple- } \\
\text { ment through IECRE }\end{array}$ & $\begin{array}{l}\text { Facilitate adoption and assess } \\
\text { value of extending to quantita- } \\
\text { tive assessment }\end{array}$ \\
\hline $\begin{array}{l}\text { H. Structural failure from snow and } \\
\text { ice (based on experience in Europe } \\
\text { and New England) }\end{array}$ & $\begin{array}{l}\text { IEC } 62938 \text { [37] Committee } \\
\text { Draft has been reviewed }\end{array}$ & $\begin{array}{l}\text { Complete IEC } 62938 \\
\text { [37]; publish in late } 2016\end{array}$ & $\begin{array}{l}\text { Encourage use of the snow } \\
\text { load test to differentiate } \\
\text { modules }\end{array}$ \\
\hline $\begin{array}{l}\text { I. Faster degradation in hot climates } \\
(\text { see }[18,19])\end{array}$ & $\begin{array}{l}\text { Delamination, encapsulant } \\
\text { discoloration, and thermal } \\
\text { fatigue are documented to } \\
\text { increase with high } \\
\text { temperature }\end{array}$ & $\begin{array}{l}\text { Define difference in use } \\
\text { environment }\end{array}$ & $\begin{array}{l}\text { Use IEC } 62892 \text { [38] to imple- } \\
\text { ment comprehensive tests at } \\
\text { higher temperatures }\end{array}$ \\
\hline J. Assessment of system functionality & $\begin{array}{l}\text { Drafts completed for both } \\
\text { energy and capacity tests }\end{array}$ & $\begin{array}{l}\text { Publication of IEC } \\
61724-2 \text { [39] and IEC } \\
61724-3 \text { [40] in } 2016\end{array}$ & Implement as part of IECRE \\
\hline
\end{tabular}

\section{A. UV Durability Testing}

IEC standards for safety requirements and tests of junction boxes (IEC 62790 [41]) and connectors (IEC 62852 [42]) were published in 2014. These both include UV exposure. Currently, the PVQAT Task Group 5 and the IEC TC 82 Weathering Group have proposed UV tests to be included in a Technical Specification (TS) (IEC 62788-7-2 [30]), which will be referenced by the IEC 62788 component standards and an amendment to IEC 61730 [31] requiring UV stability of insulating materials. The TS and amendment are being finalized in parallel, with publication anticipated in 2016.

The effects of UV are frequently observed to be strongly dependent on temperature (see Fig. 2) [43]. The primary change in exposure conditions between Qualification Plus and the proposed exposure for IEC 61730 [31] is a higher temperature during exposure to reflect the elevated module temperatures encountered in field installations. IEC 62788-7-2 [30] includes several temperatures for characterization purposes. Understanding this temperature dependence will be key to 
defining climate-specific tests and metrics for service life predictions, and has been a primary focus of PVQAT experiments [43], see Fig. 2.

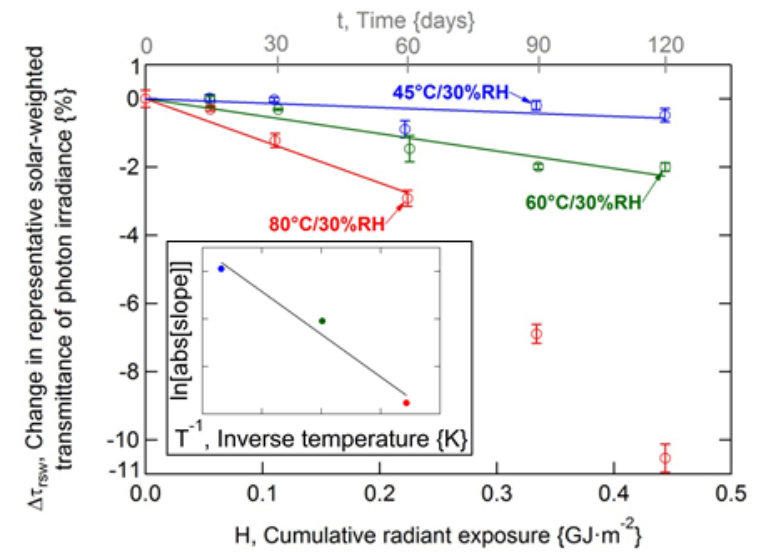

Fig. 2. Data showing temperature-dependent UV-induced degradation of optical transmittance of a susceptible encapsulant material, see [43].

\section{B. Bypass Diode Testing}

For bypass diode testing, five issues and associated actions have been identified: 1) prolonged operation at high temperature: requires a thermal endurance test such as was proposed in Qualification Plus, 2) electrostatic discharge (ESD) events may occur in the factory during assembly: IEC/TS 62916 [44] defines the required manufacturing environment to be controlled by the QMS, 3) thermal runaway when the bypass diode temperature exceeds that allowed during reverse bias: IEC 62979 [45], 4) thermal fatigue causes failure of the electrical connection to the diode: propose to flow current through the bypass diodes during the last 50 cycles of thermal cycling, and 5) functionality of the bypass diodes needs to be checked as part of any module stress test (amendments to IEC 61215 [34] and IEC 61730 [31]).

\section{Electrical Failures}

Failures of solder bonds and ribbon interconnects can lead to arcing and fires, implying a serious safety hazard as well as the potential for substantial power loss. Thermal cycling is effective at identifying poor designs or poor implementations of designs. While ribbon failures may be induced in a one-day cyclic mechanical loading test [46], damage accumulation in solder bonds requires thermal cycling. The failure rate and acceleration factor may both depend on details of the module design and implementation, implying that the thermal cycles needed to give confidence in the warranty depend on control of such things as the mass of the applied solder and the composition and cleanliness of the solder, flux, and bonding surfaces. PVQAT studies imply that the number of cycles needed to give confidence in the warranty depends on the solder composition, the control of the manufacturing process, the deployment location, etc. If the control of these factors is unknown, it is unclear how to account for them when designing the general test. A longer thermal cycling test provides added confidence, but a service life prediction will require a product-specific test.

\section{Power Loss from Cracked Cells}

It has been shown [25]-[27] that cell cracks caused by application of mechanical load may not result in loss of power output until the module has additionally been subjected to thermal cycling and/or the humidity freeze test. The addition of 1000 cycles of mechanical loading after the UV exposure in IEC 61215 [34], as proposed in Qualification Plus [5], should identify modules that will be susceptible to power loss from cracked cells. A similar approach of applied stress simulating that experienced during transportation [47], followed by thermal cycling and humidity freeze is nearing completion as IEC 62759-1 [33].

\section{E. Potential-Induced Degradation (PID)}

Two test methods have been defined in IEC/TS 62804 [35], which should be published in late 2015. However, pass/fail criteria that could be used in IEC 61215 [34] have not been agreed upon. Nevertheless, companies today routinely label their products as "PID resistant," "PID free," or "Anti-PID," often without identifying the associated test. Studies have shown that correlation of test results with outcomes in the field is complex because of variable exposure conditions and because of reversibility of the degradation [48]-[50]. While we learn more about appropriate pass-fail criteria, we recommend standardization of the terms used to describe products.

\section{F. Hot Spot Testing}

Edition 3 of IEC 61215 [34] is proposed to have an improved hot-spot test [5]. However, the hot-spot test proposed for thin-film modules still needs improvement.

\section{G. Assessment of Quality Management Systems (QMS)}

PV customers frequently express concern that the bill of materials is not adequately controlled and that the QMS may not be implemented consistently, possibly resulting in inferior product being shipped. IEC/TS 62941 [36] was written to include PV-specific QMS features including that:

- The design, process controls, and control of incoming materials are aligned with meeting the product warranty,

- The assigned power rating for each module is consistent with the advertised power rating,

- Traceability is maintained in case a recall is required, and

- Factory conditions are maintained to avoid damage of bypass diodes by electrostatic discharge.

IEC/TS 62941 [36] is scheduled for publication before the end of 2015. For this to be a useful tool, it will need to be implemented consistently. The IECRE is developing requirements for auditor training and audit best practices such as a) documenting all aspects of the QMS, b) asking probing questions, and c) including physical inspections. 
The need for a robust QMS, ongoing testing of product from the line, and the need to increase sample sizes were highlighted in the description of Qualification Plus [5], [14].

\section{H. Snow and Ice Damage}

Bent frames can occur (Fig. 3) in climates with snow and ice. The snow may partially melt and then refreeze along the bottom edge of the module, causing stress on the frame. IEC 62938 "Non-uniform snow load testing for photovoltaic (PV) modules," [37] is planned for publication in 2016 based on studies by Reil, et al [51]. This test will be valuable for those choosing modules for cold (icy) locations.

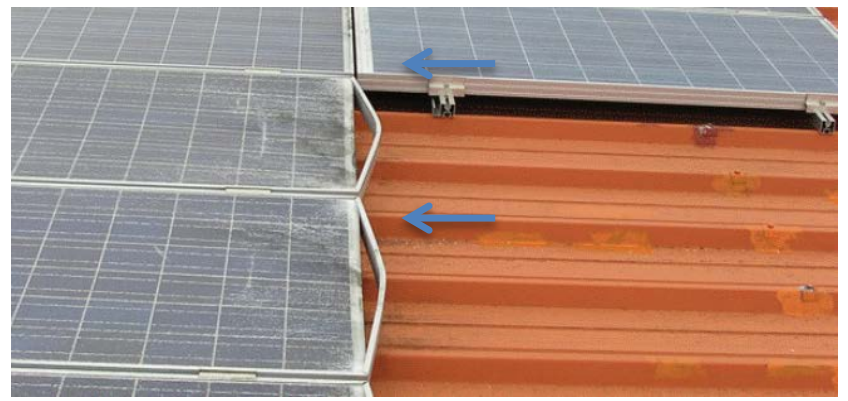

Fig. 3. Snow and ice can bend frames, as noted by two arrows.

\section{Special Testing Needs for Hot Climates}

Those preparing for massive deployments of PV in India, the Middle East, and Africa recognize that their locations may be more stressful than elsewhere. IIT Bombay has studied PV degradation in various locations in India, finding more degradation in the hotter climate zones [52]. This shared problem has inspired collaboration between PV experts in multiple hot countries and a workshop is planned for fall of 2015 in India to discuss the requirements needed for hot areas.

The climate zones defined in IEC 60721-2-1: 1987 [53] identify peak ambient temperatures of $55-60^{\circ} \mathrm{C}$ for the "Extremely warm dry climate," which is likely to result in peak module temperatures of around $85^{\circ} \mathrm{C}$ and $110^{\circ} \mathrm{C}$ for open-rack and close-roof mounting, respectively. IEC 61730 [31] sets the expectation that modules will be suitable for operation "in an environmental temperature range of $-40^{\circ} \mathrm{C}$ to $+40{ }^{\circ} \mathrm{C}$ " by specifying a temperature test (MST 21) that is referenced to $40^{\circ} \mathrm{C}$ ambient. We propose as a starting point for discussion that modules to be used at a higher temperature, $x^{\circ} \mathrm{C}$ ambient, be tested by:

- Measuring the MST 21 reference temperature [31] using $x^{\circ} \mathrm{C}$ instead of $40^{\circ} \mathrm{C}$ or increase the default temperature above $90^{\circ} \mathrm{C}$ by $x-40$.

- Increasing the maximum module temperature reached in the thermal cycling test by the difference between the measured reference temperature just described and $90^{\circ} \mathrm{C}$.

- Applying standard damp heat conditions [31] since the hottest environments seldom observe high humidity at the same time.
A climate- and use-environment-specific set of tests [54] has been proposed in IEC 62892 [38]. The applicability of IEC 62892 to meet the needs of hot climates will be discussed at a workshop in India in fall of 2015.

\section{J. System-Level Standards}

Ultimately, a PV customer requires not only that components have been designed and manufactured correctly, but that the entire system has been assembled and functions correctly. IECRE was formed under IEC's Conformity Assessment Board to have oversight of system-level certifications of Renewable Energy Systems [55]. Kelly, et al, reviews standards for design, installation, commissioning, operations and maintenance in this proceedings [1].

Standardization of system assessments will be challenging because of local requirements and component selection. Assessment at the factory alone is not adequate since components may be damaged during transportation, storage or installation. For example, if modules are walked upon or handled by their cables, the effects of the damage may appear later. Installers must follow the manufacturer's guidelines for installation, or the system is at risk.

One very important aspect of assessing the health of a PV plant is measuring the output power and/or energy with appropriate correction for the prevailing conditions. IEC 61724 has defined PV system measurements. IEC is now considering methods for both capacity and energy tests as IEC 61724-2 [39] and IEC 61724-3 [40], respectively. These are expected to be published in 2016 and will be referenced by IECRE as part of a more comprehensive assessment, which should be available in 2016 .

\section{SERVICE LIFE PREDICTIONS}

Section III identified pathways to qualification testing relevant to a range of use environments, but the community would also like to define how to predict the service life. Accurate service life predictions are almost impossible when products change faster than the time required to design and verify the model. But, some companies have designs that are stable enough to allow useful lifetime models [56]. These are especially successful if the aspect of a product that determines degradation or failure has been frozen in the design and process window.

Generic lifetime models that can be tested in a short time usually have very high uncertainties [57]. Accurate service life predictions models must be tied to 1) the specific bill of materials, 2) the specific use environment, and 3) the process window defined by the QMS. Figure 4 considers a baseline stress test that predicts 25 years life, then estimates the lifetimes that would be expected if this same test were applied to a similar, but slightly different module. For example, an encapsulant that uses a different UV absorber may exhibit different degradation kinetics (e.g. different activation 
energy). If the baseline accelerated test gives confidence for 25 years in Munich for a module with encapsulant that degrades with an activation energy of $1.1 \mathrm{eV}$, if the new material degrades with an activation energy of $0.6 \mathrm{eV}$ the same test would give confidence in only $\sim 3$ y lifetime [58] (Fig. 4). Similarly, if the module predicted to last $25 \mathrm{y}$ in Munich were deployed in Phoenix or Riyadh, the expected lifetime would drop even more [58] (Fig. 4). Finally, if the solder bonds are made with a smaller amount of solder and accumulate damage $5 \mathrm{X}$ faster than expected, the service life could be similarly reduced (Fig. 4).

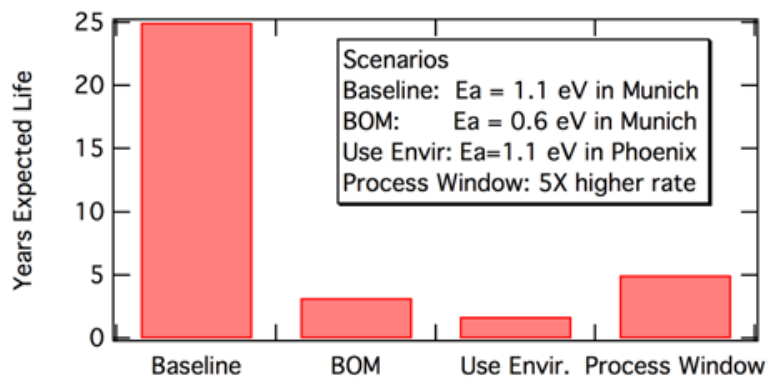

Fig. 4. Extreme examples of how a baseline service life prediction could be in error if there is a change in the bill of materials (BOM), the use environment, or the process window. Smaller variations will be found when stress conditions are chosen with smaller acceleration factors, but then the tests must run longer, as well.

Thus, as clearly seen in Fig. 4, a meaningful service life prediction must be tied directly to the QMS including the specific bill of materials and any variations in the process that affect either the aging rate or the acceleration factor for the test. Ideally, stress testing is applied to reflect the full process window allowed by the QMS. Also, a quantitative predicted lifetime must reflect the desired failure statistics; 'zero failures' is not a practical goal.

Ultimately, as process control windows are tightened, PV manufacturers will be able to reduce the length of the stress test while retaining confidence in the warranty. Thus, ironically, 200 thermal cycles for a company that maintains excellent control over the soldering process may provide confidence in a longer lifetime than a 500 thermal cycle test for a product that is only loosely controlled (though this can be improved if many modules are tested rather than the currently required two modules). This highlights the challenge of defining a meaningful generic test and motivates movement toward product-specific service life prediction away from generic type tests that apply the same test to every product.

\section{SUMMARY}

PVQAT and IEC efforts to define improved PV standards are moving forward quickly to support the maturation of the industry. IEC Technical Committee 82 is currently working on more than 80 documents with support from twelve PVQAT task groups, representing the enormity of what needs to be accomplished; this paper identifies some of the highest priority documents to be completed soon. The challenge is to identify short test methods that adequately assess durability in a range of use environments while recognizing that quantitative lifetime assessment must be implemented for a specific bill of materials with a defined quality management system that specifies the variability allowed for the product implementation. PVQAT investigations will provide a basis for implementation of both climate-specific qualification tests and more quantitative service life predictions. Today's most critical issues will be addressed by standards completed in 2015 or 2016. We are working toward the end goal of quantitative service life predictions; while models are under development today, these will have lower uncertainties when product designs stabilize enough to allow time for careful model development and validation.

\section{ACKNOWLEDGEMENT}

This work was supported by the U.S. Department of Energy under Contract No. DE-AC36-08-GO28308 with the National Renewable Energy Laboratory. We would like to acknowledge and honor the more than one hundred people who are actively involved in the IEC and PVQAT efforts.

\section{REFERENCES}

[1] G. Kelly, A. Häring, T. Spooner, G. Ball, and S. Kurtz, "Ensuring the reliability of PV systems through the formation of the IECRE Conformity Assessment System and the development of new International Standards," 42nd IEEE Photovoltaic Specialists Conference, 2015.

[2] S. Pingel, O. Frank, M. Winkler, S. Daryan, T. Geipel, H. Hoehne and J. Berghold, "Potential Induced Degradation of solar cells and panels," $35^{\text {th }}$ IEEE Photovoltaic Specialists Conference, 2010, pp. 002817-002822.

[3] R. Ross, "PV reliability development lessons from JPL's flat plate solar array project," IEEE Journal of Photovoltaics, vol. 4, pp. 291-298, 2014.

[4] C. R. Osterwald and T. J. McMahon, "History of accelerated and qualification testing of terrestrial photovoltaic modules: a literature review," Prog. Photovolt: Res. Appl., vol. 17, pp. 11-33, 2009.

[5] S. Kurtz, J. Wohlgemuth, M. Kempe, N. Bosco, P. Hacke, D. Jordan, D. Miller, T. Silverman, N. Phillips, T. Earnest, and R. Romero, "Photovoltaic Module Qualification Plus Testing," 30 pp.; NREL Report No. TP-5200-60950.

[6] D. Cunningham, B. Jaeckel, and A. Roth, "A new approach for holistic PV module quality assurance by extended stress testing and production monitoring," PV Module Reliability Workshop, Golden, CO, 2012. 
[7] B. Jaeckel, A. Krtschil, D. Cunningham, N. Forney, C. LaMothe, A. Nguyen, M. Disser, and A. Roth, "A new standard for holistic quality assurance," 26th European PVSEC, Hamburg, 2011, pp. 4 AV.2.1 3484-3490.

[8] A. Funcell, "The thresher test: crystalline silicon terrestrial photovoltaic modules long term reliability and degradation," PV Module Reliability Workshop, Golden, CO, 2012.

[9] J. Meydbray, "Reliability demonstration test," $P V$ Module Reliability Workshop, Golden, CO, 2012.

[10] D. Meakin, "Photovoltaic durability initiative (PVDI): a durability program providing bankability and marketing leverage," PV Module Reliability Workshop, Golden, CO, 2012.

[11] G. TamizhMani, "Long-term sequential testing (LST) of PV modules," PV Module Reliability Workshop, Golden, CO, 2012.

[12] "Introducing 'Best of modules' quality assurance," $P V$ Magazine, vol. 2011, pp. 92-107, 2011.

[13] K.P. Scott and A. Zielnik, "Atlas 25plus - long term durability test for PV modules," PV Module Reliability Workshop, Golden, CO, 2012.

[14] J. Wohlgemuth and S. Kurtz, "Photovoltaic module qualification plus testing," IEEE 40th Photovoltaic Specialist Conference, 2014, pp. 3589-3594.

[15] D.C. Jordan and S.R. Kurtz, "Photovoltaic degradation rates-An analytical review," Progress in Photovoltaics: Research and Applications, vol. 21, pp. 12-29, 2013.

[16] B. Müller, L. Hardt, A. Armbruster, K. Kiefer, and C. Reise, "Yield predictions for photovoltaic power plants: empirical validation, recent advances and remaining uncertainties," 29th European Photovoltaic Solar Energy Conference, Amsterdam, Netherlands, 2014.

[17] M. Köntges, S. Kurtz, C. Packard, U. Jahn, K.A. Berger, K. Kato, T. Friesen, H. Liu, and M. Van Iseghem , "Review of failures of photovoltaic modules," IEA-PVPS T13-01: 2014.

[18] R. Dubey, S. Chattopadhyay, V. Kuthanazhi, J.J. John, J. Vasi, A. Kottantharayil, B.M. Arora, K.L Narsimhan, V. Kuber, C.S. Solanki, A. Kumar, and O.S. Sastry, ., "Performance degradation in fieldaged crystalline silicon PV modules in different Indian climatic conditions," IEEE 40th Photovoltaic Specialist Conference, , 2014, pp. 3182-3187.

[19] J. Belmont, K. Olakonu, J. Kuitche, and G. TamizhMani, "Degradation rate evaluation of 26year-old $200 \mathrm{~kW}$ power plant in a hot-dry desert climate," IEEE 40th Photovoltaic Specialist Conference, 2014, pp. 3162-3166..

[20] A. Dolara, S. Leva, G. Manzolini, and E. Ogliari, "Investigation on performance decay on photovoltaic modules: snail trails and cell microcracks," IEEE Journal of Photovoltaics, pp. 1204-1211, Sept. 2014.
[21] S. Djordjevic, D. Parlevliet, and P. Jennings, "Detectable faults on recently installed solar modules in Western Australia," Renewable Energy, vol. 67, pp. 215-221, July 2014.

[22] M. Munoz, M. Alonso-Garcia, N. Vela, and F. Chenlo, "Early degradation of silicon PV modules and guaranty conditions," Solar Energy, vol. 85, pp. 2264-2274, 2011.

[23] M. A. Mikofski, D. Kavulak, D. Okawa, Y.-C. Shen, A. Terao, M. Anderson, W. Caldwell, D. Kim, N. Boitnott, J. Castro, L. Laurio Smith, R. Lacerda, and E. Hasselbrink, Jr., "PVLife: an integrated model for predicting PV performance degradation over 25+ years," 38th IEEE Photovoltaic Specialists Conference, 2012, pp. 001744-001749.

[24] J. Mallineni, B. Knisely, K. Yedidi, S. Tatapudi, J. Kuitche, and G. Tamizhmani, "Evaluation of 12year-old PV power plant in hot-dry desert climate: Potential use of field failure metrics for financial risk calculation," IEEE 40th Photovoltaic Specialists Conference, 2014, pp. 3366-3371.

[25] J. Wohlgemuth, D. Cunningham, N. Placer, G. Kelly, and A. Nguyen, "The effect of cell thickness on module reliability," 33rd IEEE Photovoltaic Specialists Conference, 2008, pp. 1-4.

[26] S. Pingel, Y. Zemen, O. Frank, T. Geipel, and J. Berghold, "Mechanical stability of solar cells within solar panels," presented at the Proc. of 24th EUPVSEC, 2009, pp. 3459-3464.

[27] S. Koch, J. Kupke, D. Tornow, M. Schoppa, S. Krauter, and P. Grunow, "Dynamic mechanical load tests on crystalline silicon modules," 25th EUPVSEC, Valencia, 2010, p. 3998.

[28] M. Kontges, S. Kajari-Schroder, and I. Kunze, "Crack statistic for wafer-based silicon solar cell modules in the field measured by UV fluorescence," IEEE Journal of Photovoltaics, vol. 3, pp. 95-101, 2013.

[29] G. Mathiak, J. Beniaminova, L. Pohl, J. Sommer, W. Herrmann, F. Reil, J. Althaus, U. Yusufoglu, J. van Mölken, and S. Hoff, "Quantitative electroluminescence imaging applied to hail impact damages," 29th European Photovoltaic Solar Energy Conference, Amsterdam, Netherlands, 2014, pp. 3285-3287.

[30] IEC/TS 62788-7-2: Measurement procedures for materials used in photovoltaic modules - Part 7-2: Environmental exposures - Accelerated weathering tests of polymeric materials, to be published.

[31] IEC 61730, ed. 2: Photovoltaic (PV) module safety qualification, to be published.

[32] IEC/TS 62782: Dynamic mechanical load testing for photovoltaic (PV) modules, to be published.

[33] IEC/TS 62759-1: Photovoltaic (PV) modules Transportation testing - Part 1: Transportation and shipping of module package units, to be published. 
[34] IEC 61215, ed. 3: Crystalline silicon terrestrial photovoltaic (PV) modules - Design qualification and type approval, to be published.

[35] IEC/TS 62804: Test methods for detection of potential-induced degradation of crystalline silicon photovoltaic (PV) modules, to be published.

[36] IEC/TS 62941: Guideline for increased confidence in $P V$ module design qualification and type approval, to be published.

[37] IEC 62938: Non-uniform snow load testing for photovoltaic (PV) modules, to be published.

[38] IEC 62892: Testing of PV modules to differentiate performance in multiple climates and applications, to be published.

[39] IEC 61724-2: Photovoltaic system performance Part 2: Capacity evaluation method, to be published.

[40] IEC 61724-3: Photovoltaic system performance Part 3: Energy evaluation method, to be published.

[41] IEC 62790:2014: Junction boxes for photovoltaic modules - Safety requirements and tests, 2014.

[42] IEC 62852:2014: Connectors for DC-application in photovoltaic systems - Safety requirements and tests, 2014.

[43] D. Miller, E. Annigoni, A. Ballion, J. Bokria, L. Bruckman, D. Burns, L. Elliott, R. French, S. Fowler, X. Gu, C. Honeker1, M. Kempe, H. Khonkar, M. Köhl, P. Krommenhoek, and L. Perret-Aebi, "Degradation in PV encapsulation transmittance: an interlaboratory study towards a climate-specific test," 42nd IEEE Photovoltaic Specialists Conference, 2015.

[44] IEC/TS 62916: Bypass diode electrostatic discharge susceptibility testing for photovoltaic modules, to be published.

[45] IEC 62979: Photovoltaic module bypass diode thermal runaway test, to be published.

[46] N. Bosco, T. Silverman, J. Wohlgemuth, S. Kurtz, M. Inoue, K. Sakurai ,T. Shioda, H. Zenkoh, K. Hirota, M. Miyashita, T. Tadanori, and S. Suzuki, "Evaluation of dynamic mechnical loading as an accelerated test method for ribbon fatigue," 29th EUPVSEC, Amsterdam, Netherlands, 2014, pp. 2484-2489.

[47] J. Althaus, F. Reil, and K. Strohkendl, "IEC proposal for testing transport stresses," SOPHIA workshop, 2012.

[48] H. Nagel, R. Pfeiffer, A. Raykov, and K. Wangemann, "Lifetime warranty testing of crystalline silicon modules for potential-induced degradation," 27th EUPVSEC, Frankfurt, Germany, 2012, pp. 3163-3166.
[49] B. Jaeckel, M. Cosic, and J. Arp, "Investigation of c$\mathrm{Si}$ modules degradation and recovery effect under high potentials," in 29th EUPVSEC, Amsterdam, Netherlands, 2014, pp. 3350-3354.

[50] P. Hacke, K. Terwilliger, R. Smith, S. Glick, J. Pankow, M. Kempe, S. Kurtz, I. Bennett and M. Kloos, "System voltage potential-induced degradation mechanisms in PV modules and methods for test," 36th IEEE Photovoltaic Specialists Conference, 2011.

[51] F. Reil, G. Mathiak, K. Strohkendl, S. Raubach, C. Schloth, B. v. Wangenheim, et al., "Experimental testing of PV modules under inhomogeneous snow loads," 27th EUPVSEC, Frankfurt, Germany, 2012, pp. 3414-3417.

[52] R. Dubey, S. Chattopadhyay, V. Kuthanazhi, J.J. John, J. Vasi, A. Kottantharayil, B.M. Arora, K.L. Narsimhan, V. Kuber, C.S. Solanki, A. Kumar. and O.S. Sastry, "Performance degradation in field-aged crystalline silicon PV modules in different Indian climatic conditions," 40th IEEE Photovoltaic Specialists Conference, Denver, CO, 2014.

[53] IEC 60721-2-1:1987: Classification of environmental conditions. Part 2: Environmental conditions appearing in nature. Temperature and humidity, 1987.

[54] J. Wohlgemuth, S. Kurtz, T. Sample, M. Yamamichi, and M. Kondo, "Development of comparative tests of PV modules by the International PV QA Task Force," 40th IEEE Photovoltaic Specialists Conference, 2014.

[55] G. Kelly, T. Spooner, G. Volberg, G. Ball, and J. Bruckner, "Ensuring the reliability of PV systems through the selection of international standards for the IECRE Conformity Assessment System," 40th IEEE Photovoltaic Specialists Conference, 2014.

[56] M. Mikofski, M. Anderson, S. Caldwell, D. DeGraaff, E. Hasselbrink, D. Kavulak, R. Lacerda, D. Okawa, Y.C. Shen, A Tedjasaputra, A. Terao, and Z. Xie, "A dynamic cell-by-cell PV system model to predict lifetime performance and reliability," $26^{\text {th }}$ EUPVSEC, 2011.

[57] M.D. Kempe, "Evaluation of the uncertainty in accelerated stress testing," 40th IEEE Photovoltaic Specialist Conference, , 2014, pp. 2170-2175.

[58] S. Kurtz, K. Whitfield, G. TamizhMani, M. Koehl, D. Miller, J. Joyce, J. Wohlgemuth, N. Bosco, M. Kempe and T. Zgonena, "Evaluation of hightemperature exposure of photovoltaic modules," Progress in Photovoltaics: Research and Applications, vol. 19, pp. 954-965, December 2011. 